\title{
From bench to bedside: Colistin nephrotoxicity and vitamin $\mathrm{E}$
}

\author{
Omid Moradi $^{*}$, Zahra Sahraei ${ }^{1}$ and Sara Asadi ${ }^{2}$ \\ ${ }^{1}$ Department of Clinical Pharmacy, School of Pharmacy, Shahid Beheshti University of Medical Sciences, Tehran, Iran \\ ${ }^{2}$ Department of Clinical Pharmacy, School of Pharmacy, Shiraz University of Medical Sciences, Shiraz, Iran
}

\section{Introduction}

By increasing the prevalence of infections caused by multi-drug resistance gram negative bacillus bacteria and mortality due to hospital acquired infections, we are using an old but not forgotten antibiotic called colistin [1-3]. Based on previous studies it was reported that about half of the isolated gram negative bacillus bacteria or even more are resistant to most of the antibiotics in our country and we are facing some problems in controlling and managing them [4,5]. Colistin, a polymyxin structured antibiotic is sometimes our only option. It was first discovered in 1949. By increasing bacterial cell membrane permeability by acting like a cationic detergent in gram negative bacteria colistin could have its bactericidal effect [6-8]. It is eliminated from kidney by renal tubular secretion, and also $80 \%$ of secreted medication reabsorbed in tubules [9]. Colistin nephrotoxicity as a serious adverse drug reaction which is mostly reversible but sometimes irreversible need special attention [10]. The exact mechanism of this reaction is not fully understood but, data from clinical studies suggest that oxidative stress and cell apoptosis play a role in acute tubular necrosis due to colistin consumption and this oxidative stress increase activity of Endothelial Nitric Oxide Synthase and Inducible Nitric Oxide Synthase which could lead to apoptosis and necrosis $[11,12]$. It also causes cellular permeability control dysfunction which could lead to cell lysis and acute tubular necrosis $[13,14]$. Although the exact mechanism is not recognized yet, it seems Reactive Oxygen Species (ROS) play an important role in tubular cells apoptosis [15]. In animal studies, it was shown before that using an antioxidant like $\mathrm{N}$-acetyl cysteine or ascorbic acid could decrease ROS level an apoptosis [12,1618]. Using ascorbic acid by dose of 3000 milligrams daily concomitantly by colistin may lead to lower acute kidney injury [11]. Vitamin E as a nutrient which approved to be used by human by Food and Drug Administration in 1969 is a fat-soluble vitamin has antioxidant effect and could decrease cellular damage by oxidant agents $[19,20]$. Alphatocopherol which possess most anti-oxidant activity amongst different vitamin $\mathrm{E}$ forms acts as a radical scavenger could protect unsaturated fatty acid in the structure of cell membrane from oxidative agent damage [21]. In an animal study it is shown that alpha-tocopherol could effect on colistin nephrotoxicity due to its antioxidant effect and radical scavenging when used concomitantly by colistin [22]. In an animal study, which considered to examine the effect of vitamin $\mathrm{E}$ on colistin nephrotoxicity, vitamin $\mathrm{E}$ as alpha-tocopherol initiated before colistin initiation with the dose of $200 \mathrm{mg}$ per day and vitamin $\mathrm{E}$ showed its protective properties and rodents which received vitamin $\mathrm{E}$ had lower serum creatinine level. They started vitamin E before colistin initiation with this rational that the animal stabled in a good antioxidant serum level. This effect is also proven by pathologic data from another animal study [22,23]. Alpha tocopherol also were effective in reducing renal damage induced by other agents such as aminoglycoside which oxidative stress have a role $[24,25]$. Based on these data we thought to conduct a randomized trial to assess alpha-tocopherol effect on colistin nephrotoxicity in Loghman-Hakim hospital, a referral tertiary teaching medical center. Patients who are candidate to receive colistin to treat infections caused by multi-drug resistance gram negative bacillus are randomly assigned to receive $400 \mathrm{mg}$ vitamin $\mathrm{E}$ in form of alpha tocopherol per day concomitantly by colistin or receive colistin alone. The trial is registered in the Iranian Registry on Clinical Trials by the code of IRCT20130917014693N8. After finishing of the study results will be published.

\section{References}

1. Li J, Nation RL, Turnidge JD, Milne RW, Coulthard K, et al. (2006) Colistin: the reemerging antibiotic for multidrug-resistant Gram-negative bacterial infections. Lancet Infect Dis 6: 589-601. [Crossref]

2. Lim LM, Ly N, Anderson D, Yang JC, Macander L, et al. (2010) Resurgence of colistin a review of resistance, toxicity, pharmacodynamics, and dosing. Pharmacotherapy 30 1279-1291. [Crossref]

3. Nation RL, Li J (2009) Colistin in the 21st century. Curr Opin Infect Dis 22: 535-543. [Crossref]

4. Moradi J, Hashemi FB, Bahador A (2015) Antibiotic resistance of Acinetobacter baumannii in Iran: a systemic review of the published literature. Osong Public Health Res Perspect 6: 79-86. [Crossref]

5. Yaghoobi MH, Arabestani MR, Karami P, Khaledi A, Seifrabie MA, et al. (2018) The pattern of antibiotic resistance of common bacteria causing nosocomial infections. Mid East Jour Family Med 7: 19.

6. MacLaren G, Spelman D. Polymyxins: An overview UpToDate 2018 [updated Feb 07, 2018; cited july 08, 2018]; Available from: https://www.uptodate.com/contents/ polymyxins-an-overview.

7. Li J, Turnidge J, Milne R, Nation RL, Coulthard K (2001) In Vitro Pharmacodynamic Properties of Colistin and Colistin Methanesulfonate against Pseudomonas aeruginosaIsolates from Patients with Cystic Fibrosis. Antimicrob Agents Chemother 45: 781-785. [Crossref]

8. Evans ME, Feola DJ, Rapp RP (1999) Polymyxin B sulfate and colistin: old antibiotics for emerging multiresistant gram-negative bacteria. Ann Pharmacother 33: 960-967. [Crossref]

9. Honoré PM, Jacobs R, Joannes-Boyau O, Lochy S, Boer W, et al. (2014) Continuous renal replacement therapy-related strategies to avoid colistin toxicity: a clinically orientated review. Blood Purif 37: 291-295. [Crossref]

10. Spapen H, Jacobs R, Van Gorp V, Troubleyn J, Honoré PM (2011) Renal and neurological side effects of colistin in critically ill patients. Ann Intensive Care 1: 14 [Crossref]

${ }^{\star}$ Correspondence to: Omid Moradi, Department of Clinical Pharmacy, Faculty of Pharmacy, Shahid Beheshti University of Medical Sciences, Tehran, Iran, Tel: +98-933-463-4004, Email: O_moradi@outlook.com

Received: July 31, 2019; Accepted: August 19, 2019; Published: August 22, 2019 
11. Dalfino L, Puntillo F, Ondok MJ, Mosca A, Monno R, et al. (2015) Colistin-associated acute kidney injury in severely ill patients: a step toward a better renal care? A prospective cohort study. Clin Infect Dis 61: 1771-1777. [Crossref]

12. Ozkan G, Ulusoy S, Orem A, Alkanat M, Mungan S, et al. (2013) How does colistininduced nephropathy develop and can it be treated?. Antimicrob Agents Chemother 57: 3463-3469. [Crossref]

13. Falagas ME, Fragoulis KN, Kasiakou SK, Sermaidis GJ, Michalopoulos A (2005) Nephrotoxicity of intravenous colistin: a prospective evaluation. Int $J$ Antimicrob Agents 26: 504-507. [Crossref]

14. Mendes CA, Burdmann EA (2009) Polymyxins: review with emphasis on nephrotoxicity. Rev Assoc Med Bras 55: 752-759. [Crossref]

15. Ceylan B, Ozansoy M, Kılıç Ü, Yozgat Y, Ercan Ç, et al. (2018) N-acetylcysteine suppresses colistimethate sodium-induced nephrotoxicity via activation of SOD2, eNOS, and MMP3 protein expressions. Ren Fail 40: 423-434. [Crossref]

16. Ozyilmaz E, Ebinc FA, Derici U, Gulbahar O, Goktas G, et al. (2011) Could nephrotoxicity due to colistin be ameliorated with the use of $\mathrm{N}$-acetylcysteine? Intensive Care Med 37: 141-146. [Crossref]

17. Yousef JM, Chen G, Hill PA, Nation RL, Li J (2012) Ascorbic acid protects agains the nephrotoxicity and apoptosis caused by colistin and affects its pharmacokinetics. $J$ Antimicrob Chemother 67: 452-429. [Crossref]
18. Yousef JM, Chen G, Hill PA, Nation RL, Li J (2011) Melatonin attenuates colistininduced nephrotoxicity in rats. Antimicrob Agents Chemother 55: 4044-4049. [Crossref]

19. Rizvi S, Raza ST, Ahmed F, Ahmad A, Abbas S, et al. (2014) The role of vitamin E in human health and some diseases. Sultan Qaboos Univ Med J 14: e157. [Crossref]

20. Singh U, Devaraj S, Jialal I (2005) Vitamin E, oxidative stress, and inflammation. Annu Rev Nutr 25: 151-174. [Crossref]

21. Engin KN (2009) Alpha-tocopherol: looking beyond an antioxidant. Mol vis 15: 855860. [Crossref]

22. Ghlissi Z, Hakim A, Mnif H, Kallel R, Zeghal K, et al. (2018) Effect of vitamin E on reversibility of renal function following discontinuation of colistin in rats: Histological and biochemical investigations. Saudi J Kidney Dis Transpl 29: 10-18. [Crossref]

23. Bader Z, Waheed A, Bakhtiar S, Khan IM (2018) Alpha-tocopherol ameliorates nephrotoxicity associated with the use of colistin in rabbits. Pak J Pharm Sci 31: 463467. [Crossref]

24. Selim A, Khalaf MM, Gad AM, Abd El-Raouf OM (2017) Evaluation of the possible nephroprotective effects of vitamin $\mathrm{E}$ and rosuvastatin in amikacin-induced renal injury in rats. J Biochem Mol Toxicol 31. [Crossref]

25. Yilmaz S, Kaya E, Comakli S (2017) Vitamin E (alpha tocopherol) attenuates toxicity and oxidative stress induced by aflatoxin in rats. Adv Clin Exp Med 26: 907-917. [Crossref]

Copyright: (C2019 Moradi O. This is an open-access article distributed under the terms of the Creative Commons Attribution License, which permits unrestricted use, distribution, and reproduction in any medium, provided the original author and source are credited. 